\title{
AKSELERASI PENGEMBANGAN AGRIBISNIS, KELEMBAGAAN KEMITRAAN IMPLEMENTASI MEWUJUDKAN PENSEJAHTERAAN PETANI HORTIKULTURA
}

\section{ACCELERATION OF AGRIBUSINESS DEVELOPMENT, IMPLEMENTATION OF PARTNERSHIP INSTITUTIONS FOR THE WELFARE OF HORTICULTURAL FARMERS}

\author{
Roosganda Elizabeth*1 ${ }^{1}$, Giovanni Inez EM ${ }^{2}$, Geraldy Samuel Ivan ${ }^{2}$ \\ ${ }^{1}$ PSEKP-Kementan \\ ${ }^{2}$ Manajemen Industri; Manajemen Agribisnis, IPB \\ *Email: roosimanru@yahoo.com \\ (Diterima 04-07-2021; Disetujui 22-07-2021)
}

\begin{abstract}
ABSTRAK
Bagi petani, hubungan kemitraan bermanfaat besar keuntungan yang relatif stabil dengan adanya kepastian pasar. Sedangkan manfaat bagi pihak mitra adalah adanya kepastian memperoleh bahan baku sesuai dengan spesifikasi yang dibutuhkan. Dengan metode deskripsi kualitatif, tulisan ini bertujuan untuk mengkaji dan mengemukakan kondisi dan kinerja kelembagaan kemitraan industri pengolah dalam pemasaran produk hortikultura. Kepastian pasar, merupakan harapan dan tujuan utama petani dalam mengusahakan setiap kegiatan usahataninya, disamping untuk memperoleh hasil panen yang maksimal tentunya. Berbagai pelaku usaha agroindustri, langsung maupun tidak langsung dalam pengadaan bahan baku sebagian besar masih berasal dari pedagang/supplier. Dalam hubungan kerjasama kemitraan, kelompok tani/gabungan kelompok tani lebih banyak dibebani kewajiban sementara itu hak-hak nya masih terbatas. Manfaat mengkaji kelembagaan kemitraan pemasaran dan perspektif pengembangannya terkait upaya akselerasi dan implementasi pengembangan agribisnis untuk peningkatan kesejahteraan petaninya, tentunya sangat dibutuhkan terutama sebagai wadah penghubung antara petani dan pengguna hasil produksi usahataninya. Perspektif pengembangan kemitraan masih sangat terbuka, antara lain disebabkan: (a) kedua belah pihak memperoleh manfaat yang saling menguntungkan; (b) permintaan produk olahan semakin meningkat seiring dengan pertambahan penduduk. Kelembagaan kemitraan berperan sebagai mitra memasarkan produksi usahatani dalam jangkauan yang lebih luas dan bervariasi. Pihak mitra terindikasi tetap memberi kesempatan menjual ke pasar bebas apabila harga lebih baik.
\end{abstract}

Kata Kunci: akselerasi, kemitraan, industri pengolah, kelembagaan, pensejahteraan petani

\section{ABSTRACT}

For farmers, the partnership relationship has great benefits, which are relatively stable with market certainty. While the benefits for partners are the certainty of obtaining raw materials in accordance with the required specifications. Using a qualitative description method, this paper aims to examine and present the conditions and institutional performance of the processing industry partnership in the marketing of horticultural products. Market certainty is the hope and main goal of farmers in pursuing each of their farming activities, in addition to obtaining maximum yields of course. Various agro-industry business actors, directly or indirectly in the procurement of raw materials, mostly still come from traders/suppliers. In a cooperative partnership relationship, farmer groups / farmer group associations are more burdened with obligations while their rights are still limited. The benefits of studying marketing partnership institutions and their development perspectives related to efforts to accelerate and implement agribusiness development to improve the welfare of their farmers, of course, are needed, especially as a liaison between farmers and users of their farm products. The perspective of partnership development is still very open, among others due to: (a) both parties obtain mutually beneficial benefits; (b) demand for processed products is increasing along with population growth. Institutional partnerships act as partners to 
market farm production in a wider and varied range. The partners are indicated to continue to provide the opportunity to sell to the free market if the price is better.

Keywords: acceleration, partnership, industry processing, institutional, farmer welfare

\section{PENDAHULUAN}

Pentingnya aspek kemitraan diawali pertengahan 1970-an hingga awal 1980-an dengan program kemitraan usaha di bidang hortikultura (PIR) (PIRPerkebunan, PIR-Perunggasan, Tambak Inti Rakyat, Tebu Inti Rakyat). Berdasar tata hubungan pengusaha (inti) dan plasma (kelompok tani), terdapat tiga pola kemitraan, yaitu: a. Perusahaan Inti Rakyat (PIR), perusahaan sebagai inti melakukan fungsi perencanaan, bimbingan dan pelayanan sarana produksi, kredit, pengolahan hasil dan pemasaran hasil bagi usahatani yang dibimbingnya, sambil menjalankan usahataninya sendiri; b. Perusahaan Pengelola, perusahaan yang melakukan perencanaan, bimbingan dan pelayanan sarana produksi, kredit, pengolahan dan pemasaran hasil usahatani yang dibimbingnya, tidak melakukan usahatani sendiri; c. Perusahaan Penghela, perusahaan melakukan perencanaan, bimbingan dan pemasaran hasil tanpa melayani kredit, sarana produksi dan juga tidak melakukan usahataninya sendiri (Elizabeth, 2017; 2018; 2019).
Produk panen hortikultura yang bersifat musiman (seasonal), mudah rusak (perishable), dan meruah (voluminous) harus segera dipasarkan dalam kondisi segar dan memerlukan biaya tambahan pengawetan supaya tidak membusuk atau rusak saat disimpan. Karena ketergantungan terhadap iklim, sebagian besar produk hortikultura tidak bisa ditanam dan dipanen sepanjang tahun (musiman) menyebabkan berlimpah pada musim panennya dan harganya merosot, serta sangat langka di musim lainnya sehingga harganya sangat mahal. Kondisi tersebut mengindikasikan aspek pemasaran merupakan titik kritis dalam rantai agribisnis (Elizabeth. 2018). Harga jual yang diterima petani masih relatif rendah karena belum seefisien dan seefektif yang diharapkan. Pemberdayaan kelembagaan kemitraan antara petani pedagang - industri pengolah merupakan alternatif pemecahan masalah pengembangan pemasaran sayuran.

Dengan metode deskriptif kualitatif, tulisan ini bertujuan mengkaji dan mengemukakan peran dan manfaat kelembagaan kemitraan petani, industri pengolah, pemasaran produk hortikultura, 
dan perspektif pengembangannya terkait pengembangan agribisnis untuk peningkatan kesejahteraan petaninya. Secara umum pengertian kemitraan mengindikasikan terdapatnya unsur pelaku (petani vs industri), bentuk, dan tujuan dalam kemitraan, adalah: jalinan kerjasama antar berbagai pelaku agribisnis, mulai dari tingkat produksi sampai ketingkat pemasaran; kerjasama antara usaha kecil dengan usaha menengah atau besar dengan memperhatikan prinsip saling membutuhkan, saling memperkuat, dan saling menguntungkan (Sayaka. 2008; dalam Elizabeth; 2011; 2016; 2017; 2018; 2019).

\section{METODE PENELITIAN}

Dalam penulisannya berbagai data dan informasi yang telah terkumpul akan dipilah dan dibahas sesuai tujuan penulisan, dikemukakan dengan metode deskriptif yang dilakukan dengan mengidentifikasi, me-review dan menganalisis berbagai implementasi program, mengevaluasi kesesuasian dan ketepatan program dan implementasinya di lapang. Untuk memperluas dan memperkaya cakupan pembahasan, dilakukan review berbagai kajian dan tulisan terkait lainnya yang telah dilakukan sebelumnya.

\section{HASIL DAN PEMBAHASAN}

\section{Kelembagaan Kemitraan Dalam Pengembangan Agribisnis Hortikultura \\ Prinsip, Pedoman, Fungsi dan Kinerja Kelembagaan Kemitraan}

Adapun beberapa pola kemitraan yang dilakukan para pelaku industri pengolahan bermacam-macam bentuknya, diantaranya: 1) Kontrak langsung dengan kelompok tani, 2) Kontrak dengan grower, selanjutnya grower bermitra dengan petani; 3) Kontrak dengan investor, selanjutnya investor yang kontrak dengan kelompok tani. Kemitraan Pelaku industri pengolahan di Jawa Tengah mengikuti pola 2 dan 3. Ada juga pelaku industri yang melakukan kemitraan hanya pada aspek pemasaran berupa jaminan harga, serta adanya pelaku industri yang memberi dan belum pernah memberikan bantuan modal kepada petani, kecuali dalam jumlah terbatas sekali seperti bibit yang dibayar setelah panen (yarnen). Walaupun demikian dengan adanya kemitraan akhirnya mengundang investor untuk masuk dalam pembiayaan sarana produksi. 
Tabel 1. Kemitraan Petani Hortikultura - Pelaku Industri Pengolahan di Jawa Tengah, 2018-2019

\begin{tabular}{cllc}
\hline Tahun Kontrak & \multicolumn{1}{c}{ Kelompok Tani } & Lokasi & Luas (ha) \\
\hline 2018 & Maju Makmur & Kuta Bawa, Purbalingga & 30 \\
& Lestari Makmur & Tajuk, Getasan, Semarang & 12 \\
& Ngudi Rizqi & Batur, Getasan, Semarang & 8 \\
& Sejati & Bumi Jawa, Brebes & 30 \\
\hline 2019 & Maju Makmur & Kuta Bawa, Purbalingga & 22 \\
& Sejati & Bumi Jawa, Brebes & 27 \\
& Setyo Tunggal & Tarubatang, Selo, Boyolali & 6 \\
& Ngudi Rizqi & Batur, Getasan, Semarang & 7 \\
& Lestari Makmur & Tajuk, Getasan, Semarang & 8 \\
\hline
\end{tabular}

Sumber: Disperindag Prov. Jateng. 2020, diolah (Elizabeth, 2021)

Beberapa tahun belakangan ini, luas areal panen komoditas hortikultura di Provinsi Jawa mengalami kecenderungan penurunan, namun tidak diikuti dengan penurunan tingkat produksi. Hal tersebut salah satunya disebabkan terjadi peningkatan produktivitas sebagai dampak positip perbaikan tahap pemeliharaan tanaman. Kemitraan pemasaran produk panen hortikultura dengan beberapa pelaku industri pengolahan di Jawa Tengah, yang mencapai areal seluas 70 ha. Sementara itu, kemitraan dengan pelaku industri pengolahan terendah di Kabupaten Semarang dan tertinggi di Kabupaten Purbalingga.

Untuk mengkaji fungsi dan kinerja kelembagaan kemitraan, penulis mengemukakan hasil temuan di Jawa Tengah, dimana secara umum, pola pemasaran produk hortikultura dapat dibedakan menjadi dua kelompok besar, yaitu pola pemasaran umum dan pola kemitraan. Untuk memenuhi bahan produksi ditangani oleh bagian procurement (pengadaan), bukan purchasing (pembelian). Dalam pemenuhan bahan baku dilakukan kemitraan dengan para petani maupun suplier. Komoditas pertanian (hortikultura) yang selama ini sudah dipasok dari kegiatan kemitraan masih sebatas cabe merah. Pelaku industri pengolahan masing-masing memiliki divisi agro processing dengan produk seperti sambal, saos, selai, asinan, manisan, dodol, kecap, keripik, dll. Pengadaan barang dilakukan pelaku industri dengan 4 cara, yaitu: (1) Impor, (2) Kontrak dengan suplier, (3) Kontrak dengan grower, dan (4) Kontrak dengan pEtani/kelompok tani/koperasi. Komposisi pengadaan pada saat ini masih didominasi oleh suplier (70\%), farmer/grower (20\%) dan impor (10\%). Di masa mendatang para pelaku industri memiliki target pengadaan dari grower/farmer bisa mencapai 40 persen, yang mengindikasikan kemungkinan 
dilakukan kontrak/kemitraan/partnership dengan petani masih sangat terbuka. Dari pola kemitraan yang ada, dapat dikemukakan bahwa: 1) Kontrak dengan grower (petani besar dengan usaha lain) dilakukan karena kelompok tani yang ada belum memiliki modal yang cukup untuk menanggung biaya pemetikan (panen), keranjang dan transportasi. Walaupun demikian pihak grower ini akan bekerjasama kelompok tan dan petani/ kelompok tani lain; 2) Kontrak dengan investor dilakukan karena kelompok tani terbatas modalnya. Jika dikaitkan dengan pengadaan bahan baku, pelaku industri pengolahan lebih memilih kelompok tani atau suplier, sebenarnya jika suplier konsisten dalam mutu lebih suka suplier. Tetapi jika kontiniutas bahan baku lebih suka dengan kelompok tani.

Dalam kemitraan, diberlakukan harga kontrak yang didasarkan pada biaya pokok ditambah keuntungan. Harga kontrak suatu komoditas hortikultura umumnya selalu mengalami peningkatan dari tahun ke tahun. Sebetulnya dengan kenaikan harga yang terus menerus setiap tahun menjadikan produk hortikultura menjadi kurang kompetitif dan bisa lebih mahal dari harga impor. Sebagai contoh pasta cabai merah yang sekarang mencapai sekitar Rp 25000/kg. Pasta diimpor terutama dari negara China dan India. Lain halnya ketika harga jual produk hortikultura (seperti: cabai merah, bawang merah, bawang putih) sedang tinggi seperti yang terjadi belakangan ini. Dalam hubungan kemitraan, (misalnya petani cabai merah) biasanya pihak pelaku industri pengolahan tidak menjadikan besaran volume definitif sebagai patokan yang harus dikirim ke pabrik. Biasanya hanya proporsi dari hasil panen yang jumlahnya bervariasi. Misalnya ada yang 75 persen hasil panen untuk Pelaku industri pengolahan dan sisanya bisa dijual ke pasar bebas, atau ada juga yang proporsinya hingga 50\%:50\%. Umumnya sebagai patokan adalah hasil panen per pohon, berkisar antara 6- 8 ons (dari sekitar 16 ons) per pohon disetor ke pelaku industri pengolahan sisanya bisa dijual bebas. Hal ini untuk mengantisipasi apabila harga di pasaran lebih tinggi, sehingga petani dapat memperoleh keuntungan yang memadai

\section{Peran Dan Fungsi Kelembagaan Kemitraan}

Tumbuhnya konsep kerjasama atau kemitraan antara perusahaan pertanian dengan pertanian rakyat didasarkan atas dua argumen yaitu: 1) adanya perbedaan dalam penguasaan sumberdaya (lahan 
dan kapital) antara masyarakat industrial di perkotaan (pengusaha) dengan masyarakat pertanian di pedesaan (petani), pengusaha mempunyai modal dan pengetahuan, sedangkan petani di sisi lain orang desa dikategorikan mempunyai lahan dan tenaga kerja, namun kurang modal dan kemampuan teknologi (keterampilan); 2) adanya perbedaan sifat hubungan biaya per satuan output dengan skala usaha pada masing-masing subsistem dari sistem agribisnis, di mana dalam subsistem usahatani, skala kecil lebih efisien atau sama efisiennya dengan skala usaha besar, karena sifat hubungan biaya per satuan output dengan skala usaha bersifat tetap (constant cost to scale). Keberhasilan hubungan kelembagaan kemitraan pelaku usaha industri maupun pemasaran karena pasar bahan baku bagi industri pengolahan yang dibinanya dapat dikuasai; sedangkan bagi petani hortikultura, kemitraan tersebut menguntungkan karena produk berbagai komoditas perkebunan yang dikembangkan menjadi memiliki jangkauan pasar lebih luas akibat dikembangkannya pabrik pengolahan dan pasar produk yang dihasilkan petani lebih terjamin (Elizabeth. 2011; 2014; 2018).
Dalam agribisnis tercakup sedikitnya 5 komponen bidang usaha, yaitu: (i) produk pertanian (komoditas primer yang belum mengalami proses pengolahan; (ii) alsintan (menyediakan dan menyalurkan sarana produksi); (iii) pemasaran berbagai hasil pertanian; (iv) agro-industri (industri pengolahan hasil pertanian); (v) pelayanan publik (perbankan, angkutan, asuransi, storage) (Elizabeth. 2016; 2019). Secara prinsip, kemitraan usaha dapat berlangsung asalkan tetap diarahkan atas dasar normanorma ekonomi. Pedoman kemitraan usaha pertanian, yang mengemukakan tentang pola-pola kemitraan usaha yang dapat dilaksanakan, antara lain pola: intiplasma, sub-kontrak, dagang umum, keagenan, dll. Dalam tahap pemasaran, pengolahan dan pengadaan saprodi, skala usaha besar lebih efisien dari pada skala kecil, karena sifat hubungan biaya per satuan output dengan skala usaha bersifat menurun (decreasing cost to scale) (Elizabeth. 2011; 2015; 2017). Sementara itu, di sektor pertanian dijumpai sedikitnya tiga pola kemitraan usaha, yaitu : (1) kemitraan yang berkembang mengikuti jalur evolusi sosio budaya atau ekonomi tradisi; (2) kemitraan program pemerintah yang dikaitkan dengan intensifikasi pertanian; dan (3) kemitraan 
yang tumbuh akibat perkembangan ekonomi pasar (Ridwan. 2011; GHP. 2013; Rachmat. 2012; Hadi. 2014; dalam Elizabeth. 2015a).

Dalam kemitraan dengan petani hortikultura yang berfluktuatif tinggi harga jualnya, para pelaku industri pengolahan tidak terlalu memberlakukan persyaratan yang ketat (Kemenkeu 2014; kemenko Ekuin. 2014; Balitbangtan 2015; Elizabeth. 2019). Memang dalam kontrak kerja ditetapkan beberapa persyaratan yang cukup ketat agar petani/suplier lebih bersungguh-sungguh untuk menghasilkan produk yang berkualitas sekaligus sebagai pendidikan agar petani lebih profesional. Bagi pelaku industri pengolahan tetap menerapkan beberapa kriteria baku yang bisa diterima si bahan baku produk olahan yang harus dimiliki produk hortikultura petani mitra. Dari pengalaman selama ini, di sisi perusahaan jika melibatkan berbagai pihak untuk proses transaksi meningkatkan biaya, antara lain untuk pembinaan dan sebagainya. Padahal dari perusahaan tidak ada alokasi untuk pembiayaan tersebut. Selain itu, keterlibatan pihak lain mungkin juga akan menambah panjang rantai pemasaran. Permasalahan juga muncul karena tidak sinkronnya harga di tingkat pabrik dan di petani. Mungkin petani melihatnya senjangnya terlalu tinggi, padahal belum tentu benar karena petani tidak mengeluarkan biaya petik, kemas maupun transport serta uang pembinaan. Selisih harga ini memang jadi masalah, karena petani menginginkan harga sesuai dengan harga pabrik.

Pembayaran kemitraan paling cepat dilakukan 2 minggu dan paling lama 3 minggu. Sebagai contoh di Banten pernah ada tersedia dana 20 juta per hektar untuk menanam komoditas hortikultura dengan luasan bisa 6 hektar dan rencana akan dilakukan kemitraan. Tetapi petani masih kurang tertarik untuk mengambil dana program tersebut dan ingin menjual bebas hasil panennya karena dipandang lebih tinggi. Dalam menjalin kemitraan para pelaku industri pengolahan berhubungan dengan petani, kelompok tani, koperasi dan LSM. Oleh karena itu, beberapa saran untuk mendapat prioritas utama untuk meningkatkan kualitas produk petani adalah perlu adanya perbaikan mutu benih dan teknologi. Selain itu pendanaan juga menjadi faktor kunci. Modal ini masih jadi kendala, terutama bagi petani kecil. Khusus untuk pemerintah hendaknya memperhatikan masalah pendanaan, pengawalan teknologi dan riset (Marimin. 2011; 
Kaniasari 2012; Kusumawardhani. 2012. Fauzi. 2014; Elizabeth 2018). Aspek riset yang utama adalah dalam perbaikan mutu benih sehingga memenuhi syarat untuk memasok kebutuhan industri.

\section{Kelembagaan Kemitraan Pemasaran: Hak dan Kewajiban}

Di beberapa daerah, kemitraan dengan pelaku industri pengolahan, dilakukan secara berjenjang, yaitu antara pelaku industri pengolahan dengan grower, grower dengan gapoktan dan antara gapoktan dengan kelompok tani. Masing-masing jenjang umumnya melakukan perjanian secara tertulis bahwa kedua pihak sepakat untuk pengikatan pengadaan jual beli produk hortikultura dari petani mitranya. Kewajiban gapoktan adalah memenuhi persyaratan teknis maupun spesifikasi dan jumlah produk panen yang ditetapkan oleh pelaku industri pengolahan (sama seperti kesepakatan yang dilakukan oleh gapoktan ke kelompok tani). Umumnya jumlah produk hortikultura yang dikirim masih lebih rendah dari kapasitas produktivitas per tanaman, yang memungkinkan dan untuk memberi kesempatan pada petani mitra menjual ke pasar apabila harga lebih baik. Sementara itu, kewajiban grower adalah membeli produk hortikultura dengan harga per kilogram yang sudah disepakati sebelumnya. Pembayaran oleh grower kepada gapoktan mitra dilakukan setiap minggu setelah barang diterima dengan sistem cek mundur atau transfer, yang tergantung pada perjanjian yang sudah disepakati bersama.

Sementara itu, kewajiban kelompok tani sebagai adalah: (a) Menanam komoditas hortikultura sesuai spesifikasi dalam jangka waktu perjanjian selama satu musim tanam (April s/d September); (b) Tidak diperbolehkan melakukan transaksi jual beli dengan pihak lain tanpa persetujuan secara tertulis sebelum memenuhi kewajiban yang telah ditentukan; sedangkan kelebihannya dapat dijual ke gapoktan dengan harga berdasarkan kesepakatan kedua belah pihak. Keuntungan dibagi dua, 50 persen untuk pihak gapoktan dan 50 persen lagi untuk kelompok tani, setelah dikurangi modal. Jika volume produk hortikultura yang dikirim kelompok tani tidak sesuai dengan ketentuan yang telah disepakati, maka pihak gapoktan berhak melakukan investigasi dan pihak Kelompok Tani berkewajiban memberikan informasi sebagaimana mestinya dan bersedia menanggung kerugian dari ketidak sesuaian kecuali force marjure. 
Meski demikian tidak semua anggota kelompok tani menggantungkan seluruh pembiayaan usahatani dari penyedia saprodi, tetapi ada yang hanya sebagian menggunakannnya, terutama untuk obat-obatan maupun pestisida yang merupakan biaya input terbesar dibandingkan dengan jumlah penggunaan biaya input lainnya, dimana harga setiap jenis obat dan pestisida terus mengalami kenaikan setiap saat dan secara umum sangat memberatkan para petani yang mengusahakan komoditas hortikultura, mengingat frekwensi penggunaan pestisida dan obat-obatan cukup tinggi.

\section{Perspektif Pengembangan dan Manfaat} Kelembagaan Kemitraan Pemasaran

Perspektif pengembangan
kemitraan pemasaran masih terbuka
antara lain disebabkan: (a) Pelaku
industri pengolahan berkeinginan
meningkatkan pengadaan dalam negeri
dengan cara kontrak langsung dengan
petani/kelompok tani sebesar 40 persen
dari kebutuhan bahan baku; (b)
Permintaan pangan, terutama produk
olahan semakin meningkat, akibat dari
pertabahan penduduk dan peningkatan
pendapatan masyarakat; (c) Adanya
kepastian pasar, mengundang
investor/Bank untuk mempermudah
aksesibibiltas modal usahatani; (d)

Pemerintah melakukan pemberdayaan Kelompok Tani, agar menjadi lebih professional, sehingga terbuka peluang untuk kemitraan. Beberapa langkah yang perlu dilakukan dalam pengembangan kemitraan, antara lain: (i) Hak dan kewajiban antara mitra dan KT sebaiknya setara, jangan sampai KT hanya dibebani dengan kewajiban yang memberatkan; (ii) Terkait dengan harga yang fluktuatif (koefisien variasi harga cabe relatif tinggi, di atas 50 persen), sebaiknya ada klausul bahwa kalau harga di pasar 50 persen lebih tinggi dari harga kontrak, maka harga kontrak perlu dievaluasi kembali; (iii) Peran pemerintah perlu ditingkatkan, untuk mendorong pemberdayaan KT dalam rangka profesionalitas KT. Menghilangkan anggapan bahwa campur tangan pemerintah dalam kemitraan merupakan biaya bagi pihak mitra; (iv) bimbingan teknik budidaya dan penanganan pasca panen selama ini masih dilakukan oleh petugas dari grower/pelaku industri pengolahan, belum melibatkan penyuluh secara aktif.

Dalam kelembagaan kemitraan antara KT (kelompok tani) dengan Pelaku industri pengolahan, kedua belah pihak saling diuntungkan. Dari sisi KT pada kemitraan berikutnya menginginkan 
perubahan. Beberapa hal yang masih perlu diperbaiki, antara lain: (a) harga dan pilihan varietas yang lebih banyak; (b) Harga beli pelaku industri pengolahan disesuaikan dengan perkembangan biaya produksi usahatani (Elizabeth 2011; 2018a; Wijaya 2011; 2013; 2014). Selama kemitraan, kesepakatan yang sudah tertulis dalam MoU tidak dapat diubah, namun untuk kemitraan berikutnya ada peluang perubahan kesepatakatan. Kasus menunjukkan bahwa, modal usaha tani diberikan dalam bentuk natura, dimana kualitas dan kuantitas tidak sesuai dengan keinginan petani. Keuntungan bagi KT adalah: (a) Adanya kepastian pemasaran hasil dan keuntungan relatif stabil; (b) Resiko kerugian lebih rendah; (c) Memperoleh kemudahan akses permodalan; (d) Memperoleh benih berkualitas serta bimbingan teknik budidaya dan penanganan pasca panen. Sementara itu, keuntungan bagi Pelaku industri pengolahan antara lain adalah dapat memperoleh bahan baku sesuai dengan spesifikasi yang diperlukan oleh pabrik. Dengan bimbingan teknik budidaya, penanganan pasca panen dan kemudahan akses modal, petani dapat memproduksi panen yang berkualitas. Sebagai perbaikan, dalam upaya pemberdayaan penyuluh di kemudian hari, maka diharapkan perlu melibatkan penyuluh untuk pembimbingan dari budibaya sampai pasca panen, serta pengaturan jadwal tanam (Elizabeth. 2013; 2017; 2017a; 2019). Perbaikan tersebut sudah ditempuh oleh pedagang padi organik di beberapa daerah di Jawa Tengah, di mana penyuluh diberi tanggung jawab pendampingan untuk menghasilkan produk berkualitas sesuai yang diinginkan pedagang.

\section{PENUTUP}

Terkait dengan masalah pemasaran hasil pertanian dan tidak seimbangnya antara penerimaan dan pengeluaran biaya usahatani menyebabkan petani sulit beranjak ke sistem usahatani yang lebih baik dan modern seperti halnya agribisnis. Pengembangan kelembagaan kemitraan dalam pemasaran diperlukan demi mendukung pengembangan agribisnis cabe merah Indonesia, juga sebagai upaya perlindungan terhadap bargaining position petani dalam pembentukan harga, saluran dan marjin pemasaran (Elizabeth. 2017; 2018; 2019). Semuanya sebagai insentif dan keberpihakan terhadap petani cabe merah dalam upaya mendukung pengembangan agribisnis cabe merah di masa depan 
yang berkesinambungan dan berkelanjutan. Dari kasus kemitraan Pelaku industri pengolahan dengan KT di Jawa Tengah, dapat dikemukakan bahwa:

(a) Cakupan kemitraan masih kecil, sehingga belum berperan dalam perekonomian Jawa Tengah;

Kemitraan yang ada langsung, maupun tidak langsung. Kemitraan tidak langsung menyebabkan KT tidak memperoleh keuntungan yang optimal dari kemitraan tersebut; (c) Kemitraan dengan harga kontrak yang sudah ditetapkan, apabila terjadi kenaikan harga, maka petani peserta kemitraan akan memperoleh keuntungan usaha tani yang lebih kecil dibandingkan dengan petani non mitra. Namun, apabila petani peserta mitra adalah petani luas, maka hal tersebut tidak terjadi; (d) Adanya kepastian pasar mendorong investor untuk memberikan pinjaman modal usaha tani, yang selama ini menjadi kendala bagi petani. Meski ada keuntungan dalam bermitra namun apabila tidak mengalami keterbatasan modal untuk budidaya komoditas hortikultura, sesungguhnya para petani lebih suka tidak menjalin kemitraan, karena terdapatnya berbagai persyaratan mitra yang dirasakan memberatkan oleh petani mitra.
KESIMPULAN DAN SARAN KEBIJAKAN

- Insiatif kemitraan pemasaran produk pertanian umumnya berasal dari pihak prosesor atau pedagang besar/eksportir, dikarenakan. keinginan memperoleh bahan baku atau produk dalam jumlah yang sesuai, kontiniu serta memenuhi kualitas yang diinginkan.

- Budidaya komoditas pertanian, relatif menguntungkan petani, tetapi pemerintah daerah harus tegas dalam membatasi areal yang bisa ditanami tanaman pangan atau hortikultura. Pemerintah, terutama pemerintah daerah, mempunyai peranan sangat besar sebagai fasilitator dalam kemitraan pemasaran produk pertanian, namun perlu dicari solusi agar prosesor tidak langsung bekerjasama dengan supplier atau kelompok tani tanpa memberitahu ke Dinas pertanian setempat karena alasan kepraktisan atau ingin menghindari birokrasi yang kurang fleksibel.

- Selain inisiatif dari pihak prosesor atau eksportir, kelompok tani atau gabungan kelompok tani bisa didorong untuk mengambil inisiatif dalam kemitraan pemasaran produk pertanian. Peranan pemerintah daerah, 
pedagang lokal maupun lembaga swadaya masyarakat (LSM) bisa membantu petani dalam menjalian kemitraan dengan prosesor atau eksportir.

- Keuntungan kemitraan pemasaran produk panen hortikultura adalah mengurangi risiko fluktuasi harga selama musim panen (harvest season) maupun setelah panen (off-season), bantuan kredit saprodi (yang bagi sebagian besar petani relatif mahal dan harus kontan).

- Kemitraan pemasaran, khususnya dengan Pelaku industri pengolahan masih dapat ditingkatkan dengan berbagai saran kebijakan, antara lain: (a) Kesetaraan hak dan kewajiban antara pelaku lebih ditingkatkan; (b) Peran pemerintah perlu ditingkatkan, tetapi fungsinya jangan merupakan biaya bagi pelaku kemitraan;

- Pemerintah daerah harus secara proaktif melatih petani melalui kelompok tani atau gabungan kelompok tani tentang cara melakukan budidaya secara baik (good agricultural practices). Disamping itu petani perlu dilatih atau diberi penyuluhan tentang sikap mental dalam melakukan kemitraan terutama dalam hal mentaati kesepakatan yang telah disetujui bersama dengan prosesor/eksportir/super market.

\section{DAFTAR PUSTAKA}

Badan Litbang Pertanian Deptan. 2015. Prospek dan Arah Pengembangan Agribisnis. Balitbang Deptan. Jakarta.

Elizabeth, R. 2008. Penguatan dan Pemberdayaan Peran Pembangunan Perekonomian, Sistem Pasar dan Kelembagaan: Dilema Dilema Kemiskinan dan Kelaparan di Perdesaan. Prosiding Seminar Nasional: "Akselerasi Inovasi Teknologi Pertanian Spesifik Lokasi Mendukung Ketahanan Pangan di Wilayah Kepulauan." BPTP Maluku Ambon, 29-30 Oktober 2007. BPTP Maluku Ambon. Balitbang. Departemen Pertanian. 2008.

Elizabeth, R. 2011. Strategi Pencapaian Diversifikasi Dan Kemandirian Pangan Dalam Rangka Mewujudkan Ketahanan Pangan: Antara Harapan Dan Kenyataan. Buku IPTEK. Pusat Penelitian dan Pengembangan Tanaman Pangan. Badan Litbang Pertanian. Kementerian Pertanian.

Elizabeth. R. 2014. Mewujudkan Kemandirian Dan Ketahanan Pangan Melalui Revitalisasi Dan Pengembangan Infrastruktur Pertanian. Konferensi Nasional XVII dan Kongres XVI PERHEPI. IPB International Convention Center (IICC). Bogor. 28-29 Agustus 2014.

Elizabeth. R. 2015. Pencapaian Daya Saing Melalui Peningkatan Teknologi Pengolahan, Peningkatan Kelembagaan Dan Pemasaran Produk Pangan Olahan. 
PERHEPI. Tema: Indonesia Menuju Swasembada Pangan Dalam Tiga Tahun Kedepan: "Tinjauan Konseptual, Teoritis dan Empiris". Kendari, 9 Maret, 2015.

Elizabeth, R. 2016. Pemberdayaan Petani Dalam Pengelolaan Tanaman Dan Ternak Guna Meningkatkan Kesejahteraan Petani. Prosiding Seminar Nasional Agustus 2016. BPTP Sulawesi Utara. Manado. Badan Litbang Pertanian. Sekretaris Jenderal Pertanian. Kementerian Pertanian.

Elizabeth. R. 2017. Revitalisasi Industri Produk Olahan Dan Pemberdayaan Lembaga Kemitraan Mendukung Peningkatan Pemasaran, Daya Saing Dan Pensejahteraan Petani Pisang. Journal of Agricultural Scienties. UNES. (Universitas Ekasakti). Padang Sumatera Barat. Volume 2. Issue 1. June 2017. ISSN Cetak: 2528-5556. ISSN Online: 2528-6226.

Elizabeth. R. 2017a. Akselerasi Pemberdayaan Dan Peningkatan Kompetensi Dalam Sistem Produksi Untuk Mengatasi Permasalahan Ekonomi Di Indonesia. Volume 2. Issue 1. June 2017. ISSN Cetak: 2528-5556. ISSN Online: 2528-6226.

Elizabeth. 2018. Akselerasi Agroindustri Dan Nilai Tambah: Faktor Pendukung Pencapaian Dayasaing Produk Dan Percepatan Pembangunan Pertanian Di Indonesia. OJS. Online Jurnal System. UNES (Univ. Ekasakti). Padang. Sumatera Barat.

Elizabeth. 2018a. Akselerasi Pencapaian Dayasaing Produk Agroindustri Melalui Revitalisasi Berkesinambungan Implementasi Pemberdayaan Kelembagaan Pertanian. Buku. Puslitbangtan. Kementerian Pertanian. Jakarta.
Elizabeth, R. 2019. Revitalisasi Implementasi Pemberdayaan Kelembagaan Pertanian Berkesinambungan Mendukung Pencapaian Dayasaing Produk Olahan. Volume 2. Issue 2. June 2019 OJS. Online Jurnal System. UNES (Univ. Ekasakti). Padang. Sumatera Barat.

Fauzi Aziz. 2014. Hilirisasi Cermin Politik Industri. Bisnis Indonesia. http://www.neraca.co.id/bisnisindonesia. (6-6-2021).

Global Humanitarian Platform. 2013. Principles of Partnership A Statement of Commitment. www.globalhumanitarianplatform.o $\mathrm{rg}$

Hadi P. 2014. Reformasi Kebijakan Penciptaan Nilai Tambah Produk Pertanian Indonesia. Reformasi Kebijakan Menuju Trasformasi Pembangunan Pertanian. Haryono (editor). Badan Litbang Pertanian.

INA (Indonesian Netherlands Association). 2007. Program Dukungan Partnership Usaha Hortikultura antara Petani Produsen Kecil Dengan Perusahaan. Jakarta. www.ina.or.id/inaweb/hpsp.php

Kaniasari, N. 2012. Meningkatkan Nilai Tambah dan Daya Saing Produk Pertanian.

Kementerian Keuangan Republik Indonesia. 2014. Laporan: Kajian Nilai Tambah Produk Pertanian. Laporan.

Kementerian Koodinator Bidang Perekonomian. 2016. Outlook Ekonomi Indonesia 2017: Melanjutkan Reformasi: Menjaga Ketahanan dan Memacu Pertumbuhan Ekonomi. Jakarta, 10 November 2016.

Kusumawardani MH. 2012. Membuat Rantai Nilai Lebih Berpihak Pada Kaum Miskin: Buku Pegangan Bagi 
Praktisi Analisis Rantai Nilai. Australian Goverment(AU): Aciar.

Marimin, dan Maghfiroh N. 2011. Aplikasi Teknik Pengambilan Keputusan dalam Manajemen Rantai Pasok. IPB Press.

MSN. 2017. Kemtan Genjot Ekspor Beras Organik. https://www.msn.com/idid/ekonomi/ekonomidanbisnis/kemt an-genjot-ekspor-beras-organik/arAAo1SLh (3 Juni 2021).

Rivani, A. dan D. Hidayat 2007. Keterkaitan Petani dengan Pemasaran: Kesejahteraan Petani dan Pengentasan Kemiskinan. CAPSA Monograph No.49, UNCAPSA-CAPSA, Bogor.

Putra I K T E, I P G Sukaatmadja, N Ny K Yasa. 2016. Perilaku Konsumen Mengkonsumsi Beras Organik Dikota Denpasar Berdasar Theory Of Planned Behavior. E-Jurnal Ekonomi dan Bisnis Univ. Udayana 5.8 (2016):2609-2638. ISSN:23373067

Rachmat, M. R. Elizabeth. Supadi. H. Supriyadi. P. U. Hadi. S. Nuryanti. 2012. Studi Kebutuhan Pengembangan Produk Olahan Pertanian Dalam Rangka Liberalisasi Perdagangan. LHP. PSEKP. Bogor. Badan Litbang Pertanian. Kementerian Pertanian. Jakarta.

Ridwan R. Model Penggilingan Padi Terpadu Untuk Meningkatkan Nilai Tambah. Buletin Teknologi Pascananen Pertanian Vol 8 (2), 2012.
Saptana, A. Agustian, H. Mayrowani, dan Sunarsih. 2006. Analisis Kelembagaan Partnership Rantai Pasok Komoditas Hortikultura. Pusat Analisis Sosial Ekonomi dan Kebijakan Pertanian. Bogor. Laporan Teknis.

Saptana, E.L. Hastuti, Ashari, K.S. Indraningsih, S. Friyatno, Sunarsih, dan V. Darwis. 2005. Analisis Kelembagaan Partnership pada Komoditas Hortikultura. Pusat Analisis Sosial Ekonomi dan Kebijakan Pertanian. Bogor.

Sayaka, B. Dkk. 2008. Pengembangan Kelembagaan Partnership Dalam Pemasaran Komoditas Pertanian. Pusat Analisis Sosial Ekonomi dan Kebijakan Pertanian. Bogor.

Susilawati S H,. H P Saliem. E. Ariningsih. R. Elizabeth. C R Addawiyah. 2018. Strategi Antisipatif Pengelolaan Surplus Produksi Padi Dan Jagung. LHP. PSEKP. Sek Jen. Kementan.

Wijaya, Tony. 2014. Nilai dan Pengetahuan sebagai Prediktor Intensi Membeli Makanan Organik. Jurnal Manajemen dan Kewirausahaan, 16:69-82.

Wijaya, Tony. 2013. Anteseden Perilaku beli Produk Ramah Lingkungan : Studi Perilaku Konsumen Makanan Organik. Jurnal Ekonomi dan Bisnis, 7(3):149-161.

Wijaya, Tony dan Hidayat, A. 2011. Model intense pembelian makanan organik, Call for Paper Update Ekonomi, Akuntansi dan Bisnis Indo Indonesia, Proceeding Fakultas Ekonomi UII,Yogyakarta. 